\title{
EFFECTS OF SOIL CONDITIONERS ON LAWN GRASS GROWTH IN DIFFERENT YEAR SEASONS
}

\author{
JANKOWSKI, K. ${ }^{{ }^{*}}$-TRUBA, M. ${ }^{1}$ - JANKOWSKA, J. ${ }^{1}$ - CZELUSCINSKI, W. ${ }^{1}$ - WISNIEWSKA- \\ KADZAJAN, B. ${ }^{1}$ - MALINOWSKA, E. ${ }^{1}-$ KOPER, O. ${ }^{1}$ - GÓRAL, P. ${ }^{1}$ - KANIA, P. ${ }^{1}-$ \\ MATSYURA, A. ${ }^{2}$ \\ ${ }^{1}$ Department of Grassland and Green Areas Creation \\ Siedlce University of Natural Sciences and Humanities \\ Boleslawa Prusa street 14, 08-110 Siedlce, Poland \\ ${ }^{2}$ Altai State University \\ Prospekt Lenina 61, 656049 Barnaul, Russia \\ *Corresponding author \\ e-mail: kazimierz.jankowski@uph.edu.pl \\ (Received $9^{\text {th }}$ Jan 2018; accepted $3^{\text {rd }}$ Apr 2018)
}

\begin{abstract}
The field experiment was conducted in Poland between 2013 and 2015. The research was carried out in the split plot design with three replications. The following grass species were used in the experiment (factor B): Lolium perenne, Festuca rubra and Poa pratensis. Another experimental factor tested in the research was soil conditioners (factor A) as Substral (S), Humus Active Papka (HAP), EkoUżyźniacz (EU), UGmax (UG). In each year of the experiment, among other things, grass growth, i.e. its slow rate of growth, was assessed. It was based on measurements of the height of plants before harvest. A 9-point scale was used. This assessment was conducted in three seasons (spring, summer, autumn). In all seasons red fescue had the most desirable intensity of growth (the slowest) and permanent ryegrass the fastest, both determined as an average effect of all soil conditioners. Of the applied soil conditioners, lawns treated with Humus Active Papka, grew the most slowly, taken as an average for all grass species and for all seasons. Of all grass species tested in the experiment red fescue had the smallest variation of growth intensity during the research.
\end{abstract}

Keywords: lawns, regrowth, soil condition, grasses, Lolium perenne, Festuca rubra, Poa pratensis

\section{Introduction}

In recent years a popular conviction has developed that presence of lawns in the vicinity of residential houses and in areas adjacent to various companies and establishments builds a positive image, demonstrating a high standard of living of their owners, or high performance in business (Czeluściński et al., 2017; Jankowski et al., 2017). In a situation when people are increasingly preoccupied with their professional life, a limited time they have to spend on treatment and maintaining lawns in a suitable condition has become a problem (Jankowski et al., 2012a,b,d,e). According to Rutkowska and Dębska-Kalinowska (2000) widely relevant species of grass planted on lawns used extensively include: red fescue (Festuca rubra), smooth-stalked meadowgrass (Poa pratensis), and perennial ryegrass (Lolium perenne).

According to many authors (Domański and Andrzejewska, 2011; Domański, 1998; Harkot and Czarnecki, 1998; Jankowski et al., 1999a,b; Prończuk and Prończuk, 2006), with a limited time devoted to lawn maintenance, a required feature of grass is its slow pace of growth. Therefore, it is important that species of grass selected for lawns should grow slowly. The slower growth of a species of grass, the more it is used as a component of a lawn mixture (Knot et al., 2017; Pooya et al., 2013; Salehi and Khosh- 
Khui, 2004). Slow growth of lawn grass considerably reduces mowing frequency, which directly translates into smaller costs of maintaining a lawn (Prończuk and Prończuk, 2008).

To make lawn maintenance simple, new solutions aiming at limiting amount of work, or at making it simpler, need to be worked out. It can be done by a proper selection of grass species, but also by use of special nutrients and growth regulators (Jankowski et al., 2012b,c,d). One of such solutions is application of organic products called soil conditioners, for a longer time positively affecting release of soil minerals and making it possible for plants to survive stressful conditions (Chen et al., 2004; Gąbka and Wolski, 2008). Use of such soil conditioners can be beneficial from a financial point of view, limiting the amount of money spent on grass lawn maintenance (Prończuk and Prończuk, 2008). Such products reduce mowing frequency, saving time and petrol, and with them applied, grass does not need as much fertiliser.

In the literature on the use of lawns there has been little information on possible use of soil additives to improve lawn maintenance. That is why, the aim of this paper is to investigate the impact of such products on grass quality, assessed by determining the rate of growth.

\section{Material and methods}

\section{Characteristics of study species}

Set up in 2012 the field experiment was conducted in the experimental facility of the Siedlce University of Natural Sciences and Humanities in Poland $\left(52^{\circ} 12^{\prime}\right.$ N, $22^{\circ} 28^{\prime}$ E) between 2013 and 2015. The research was carried out as a mini-plot experiment, in the split plot design with three replications and the plot area of $1 \mathrm{~m}^{2}$. The following grass species were used in the experiment (factor B): Lolium perenne - variety Info, Festuca rubra - variety Nil, and Poa pratensis - variety Alicja. They were sown on their own, each of them at the rate of $28 \mathrm{~g} / \mathrm{m}^{2}$.

\section{Characteristics of fertilizers}

Another experimental factor tested in the research was soil conditioners (factor A). Soil conditioners used in the experiment improve soil properties, according to the Institute of Soil Science and Plant Cultivation (IUNG) in Puławy. The composition of the soil conditioners used in the research is presented in Table 1.

The UGmax soil conditioner is an extract from compost, containing macronutrients $(\mathrm{N}, \mathrm{P}, \mathrm{K}, \mathrm{Mg}, \mathrm{Na}$ ) and micronutrients $(\mathrm{Mn})$. It also contains lactic acid bacteria, photosynthetic bacteria, Azotobacter, Pseudomonas, yeast, and Actinomycetes. The micro-organisms in the conditioner have a capacity of processing organic and natural fertilizers into compost and humus. These processes are conducive not only to the production of humus but also to improving soil structure, which in turn has a positive effect on water balance in the soil. In addition, the UGmax soil conditioner increases disease resistance, keeping plants healthy, but it also stimulates the development of the root system and supports the biological reduction of molecular nitrogen.

Humus Active Papka contains macronutrients (N, P, K, Ca, Mg), trace elements (Mn, $\mathrm{Fe}, \mathrm{Zn}, \mathrm{Cu}$ ), and active humus with useful microorganisms. According to the manufacturer Humus Active, among other beneficial effects, positively affects plant health as well as soil structure, and releases nutrients not readily available to plants. 
Table 1. Composition of soil conditioners applied in the experiment

\begin{tabular}{|c|c|c|c|c|c|c|c|c|c|c|c|c|}
\hline \multirow{2}{*}{$\begin{array}{c}\text { Soil } \\
\text { conditioner }\end{array}$} & \multicolumn{6}{|c|}{$\begin{array}{l}\text { Macronutrients } \\
\left(\mathrm{g} \cdot \mathbf{k g}^{-1}\right)\end{array}$} & \multicolumn{5}{|c|}{$\begin{array}{l}\text { Micronutrients } \\
\left(\mathrm{mg} \cdot \mathrm{kg}^{-1}\right)\end{array}$} & \multirow{2}{*}{$\begin{array}{c}\text { Microorganism and } \\
\text { others }\end{array}$} \\
\hline & $\mathbf{N}$ & $\mathbf{P}$ & $\mathbf{K}$ & Ca & $\mathbf{M g}$ & $\mathbf{N a}$ & Mn & $\mathrm{Fe}$ & $\mathbf{Z n}$ & $\mathbf{C u}$ & Mo & \\
\hline $\begin{array}{l}\text { Substral } \\
\text { (S) }\end{array}$ & 220 & 21.8 & 83 & & 12.06 & & 12 & 50 & 12.5 & 12.5 & 1 & - \\
\hline $\begin{array}{l}\text { Humus } \\
\text { Active } \\
\text { Papka } \\
\text { (HAP) }\end{array}$ & 0.2 & 1.3 & 4.6 & 3.0 & 0.5 & - & 15 & 500 & 3 & 1 & - & $\begin{array}{l}\text { Active humus with } \\
\text { useful microorganisms }\end{array}$ \\
\hline $\begin{array}{l}\text { Eko- } \\
\text { Użyźniacz } \\
\text { (EU) }\end{array}$ & 0.6 & 0.3 & 0.7 & - & - & - & - & - & - & - & - & $\begin{array}{c}\text { Endo micorhizza, } \\
\text { fungi, bacteria, } \\
\text { enzymes of earthworms }\end{array}$ \\
\hline $\begin{array}{c}\text { UGmax } \\
\text { (UG) }\end{array}$ & 1.2 & 0.2 & 2.9 & - & 0.1 & 0.2 & 0.3 & - & - & - & - & $\begin{array}{c}\text { lactic acid bacteria, } \\
\text { photosynthetic bacteria, } \\
\text { Azotobacter, } \\
\text { Pseudomonas, yeast, } \\
\text { Actinomycetes }\end{array}$ \\
\hline
\end{tabular}

Eko-Użyźniacz is extracted from bovine vermicompost and contains the main macronutrients $(\mathrm{N}, \mathrm{P}, \mathrm{K})$, micro-organisms, and enzymes related to metabolism of earthworms. This soil conditioner stimulates biological life in soil degraded chemically, mechanically, or biologically, and increases plant resistance to different stress factors.

Soil conditioners were applied annually in spring (mid-May) in the following doses: UGmax $-25 \mathrm{ml} \cdot \mathrm{m}^{-2}$ (0.6 1 in 2501 of water), Eko-Użyźniacz $-100 \mathrm{ml} \cdot \mathrm{m}^{-2}(101 \mathrm{in}$ 1001 of water), and Humus Active Papka $-250 \mathrm{ml} \cdot \mathrm{m}^{-2}$ (0.2 1 for 101 of water). In turn, Substral, a slow release fertilizer used on lawns, was used in the quantity of $20 \mathrm{~g} \cdot \mathrm{m}^{-2}$.

\section{Experimental design}

In each year of the experiment, among other things, grass growth, i.e. its slow rate of growth, was assessed. It was based on measurements of the height of plants before harvest. That assessment was made according to the methodology developed by Domański (1998). A 9-point scale was used, in which 9 meant the highest value, with the following description: 1-very high; 3-large; 5-average; 7-small; 9-very small. This assessment was conducted in three seasons (spring, summer, autumn). In each year of the research spring assessment was made around 20 May, summer assessment around 20 August, and autumn assessment around 10 October.

The experiment was set up on the soil developed from loamy sand, belonging to anthropogenic soils of the culture-earth order, and of the type of hortisole (Systematics of Polish Soils). Chemical analysis showed that the soil was alkaline, with high content of magnesium and phosphorus, and low potassium content.

\section{Characteristics of weather conditions}

Meteorological data between 2013 and 2015 were obtained from the Hydrological and Meteorological Station in Siedlce. The average air temperature during the experiment was very similar to the long-term average temperature (Table 2). In each year of the research the highest temperature was in July (19.3 on average) and August (19.0), while the lowest temperature, taking into account only the growing season, was in April (an average of 8.5) and October (an average of 8.2). 
Table 2. Average air temperature $\left({ }^{\circ} \mathrm{C}\right)$ and precipitation $(\mathrm{mm})$ in individual months of the growing seasons

\begin{tabular}{|c|c|c|c|c|c|c|c|c|}
\hline \multirow[b]{2}{*}{ Year } & \multicolumn{8}{|c|}{ Month } \\
\hline & Apr. & May & June & July & Aug. & Sept. & Oct. & Means \\
\hline \multicolumn{9}{|c|}{ Temperature $\left({ }^{\circ} \mathbf{C}\right)$} \\
\hline 2013 & 7.5 & 15.3 & 17.7 & 18.8 & 18.3 & 11.4 & 9.6 & 14.1 \\
\hline 2014 & 9.7 & 13.7 & 15.1 & 20.5 & 17.8 & 13.7 & 8.4 & 14.1 \\
\hline 2015 & 8.2 & 12.3 & 16.5 & 18.7 & 21.0 & 14.5 & 6.5 & 14.0 \\
\hline Means & 8.5 & 13.8 & 16.4 & 19.3 & 19.0 & 13.2 & 8.2 & 14.1 \\
\hline Long-term means & 8.5 & 14.0 & 17.4 & 19.8 & 18.9 & 13.2 & 7.9 & 14.2 \\
\hline \multicolumn{9}{|c|}{ Rainfall (mm) } \\
\hline 2013 & 57.6 & 145.8 & 111.9 & 49.1 & 44.1 & 86.6 & 18.0 & 73.3 \\
\hline 2014 & 39.5 & 79.5 & 74.2 & 37.5 & 105.7 & 26.3 & 3.0 & 52.2 \\
\hline 2015 & 30.0 & 100.2 & 43.3 & 62.6 & 11.9 & 77.1 & 39.0 & 52.0 \\
\hline Means & 42.4 & 108.5 & 76.5 & 49.7 & 53.9 & 63.3 & 20.0 & 59.2 \\
\hline Long-term means & 33.0 & 52.0 & 52.0 & 65.0 & 56.0 & 48.0 & 28.0 & 47.7 \\
\hline
\end{tabular}

A meteorological element with major temporal fluctuations is rainfall (Skowera and Puła, 2004). By analyzing its amount in different months of the experiment it was found that the lowest average monthly precipitation was in $2015(52.0 \mathrm{~mm})$, but still it was higher by $2.3 \mathrm{~mm}$ than the long-term average. In the growing season of 2013 the average monthly precipitation of $73.3 \mathrm{~mm}$ was the highest. May 2013 was a month in which rainfall was the highest of all months during the experiment $(145.8 \mathrm{~mm})$. The lowest rainfall was recorded in October $2014(3.0 \mathrm{~mm})$ and August $2015(11.9 \mathrm{~mm})$.

Optimal temperature and moisture conditions were only in April 2014 and in September 2015. In the remaining months of all the growing seasons the weather conditions were not as favourable, varying from extremely dry in August 2015 to extremely wet in May 2013. Throughout the experiment the best conditions occurred at the beginning of each growing season. It can be concluded that the most difficult period for plants was in 2015, when, apart from May and the end of the growing season, the weather conditions ranged from quite dry to extremely dry.

\section{Statistical analysis}

The test results were evaluated statistically with the analysis of variance. Tukey's test $(\mathrm{P} \leq 0.5)$ was used to find significantly different means of the effects of experimental factors and their interaction. Based on grass growth ratings, standard deviation and coefficient of variation were calculated for separate seasons, years, and soil conditioners.

\section{Results and discussion}

\section{Spring grass regrowth}

There was diversity of grass growth rate, depending on the species of grass, soil conditioner applied, and season of the year (Tables 3-5). In springtime this rate was varied in relation to all experimental factors (Table 3). Throughout the experiment during spring seasons, the slowest growth rate, as an average for all grass species, was in result of Humus Active Papka application (5.29) and the most intensive after using UGmax $\left(4.71^{\circ}\right)$ or Substral $\left(4.74^{\circ}\right)$. According to Prończuk and Prończuk (2006), in 
Denmark and in the Netherlands no mineral fertilisers are used on municipal lawns, which slows down the growth of grass and reduces the need for frequent mowing. In the USA, in an extensive system, most lawns (80\%) are maintained without the use of mineral fertilisers as well (Cook, 2005).

Table 3. Grass growth rates on a 9-point scale in spring seasons between 2013 and 2015

\begin{tabular}{|c|c|c|c|c|c|c|}
\hline \multirow{2}{*}{$\begin{array}{c}\text { Year } \\
\text { (C) }\end{array}$} & \multirow{2}{*}{$\begin{array}{l}\text { Species } \\
\text { (B) }\end{array}$} & \multicolumn{4}{|c|}{ Fertiliser (A) } & \multirow{2}{*}{$\bar{x}$} \\
\hline & & (S) & $(\mathbf{E U})$ & (HAP) & (UG) & \\
\hline \multirow{3}{*}{2013} & $\begin{array}{c}\text { Smooth-stalked meadow- } \\
\text { grass }\end{array}$ & 6.8 & 5.2 & 5.0 & 7.2 & 6.05 \\
\hline & Perennial ryegrass & 7.4 & 7.2 & 6.8 & 6.9 & 7.08 \\
\hline & Red fescue & 8.1 & 8.3 & 7.8 & 7.9 & 8.03 \\
\hline \multirow{3}{*}{2014} & $\begin{array}{l}\text { Smooth-stalked meadow- } \\
\text { grass }\end{array}$ & 1.0 & 7.0 & 6.9 & 2.0 & 4.23 \\
\hline & Perennial ryegrass & 1.4 & 2.9 & 3.2 & 2.3 & 2.45 \\
\hline & Red fescue & 2.3 & 2.0 & 1.8 & 2.2 & 2.08 \\
\hline \multirow{3}{*}{2015} & $\begin{array}{l}\text { Smooth-stalked meadow- } \\
\text { grass }\end{array}$ & 5.0 & 2.2 & 5.1 & 1.9 & 3.55 \\
\hline & Perennial ryegrass & 2.0 & 2.2 & 2.0 & 3.1 & 2.33 \\
\hline & Red fescue & 8.7 & 9.0 & 9.0 & 8.9 & 8.9 \\
\hline & & \multicolumn{5}{|c|}{ Mean effect of species } \\
\hline \multirow{6}{*}{\multicolumn{2}{|c|}{$\begin{array}{c}\text { Smooth-stalked meadow-grass } \\
\text { Perennial ryegrass } \\
\text { Red fescue } \\
\end{array}$}} & 4.27 & 4.8 & 5.66 & 3.7 & 4.61 \\
\hline & & 3.6 & 4.1 & 4.0 & 4.1 & 3.95 \\
\hline & & 6.37 & 6.43 & 6.2 & 6.33 & 6.33 \\
\hline & & \multicolumn{5}{|c|}{ Mean effect of fertiliser } \\
\hline & & 4.74 & 5.11 & 5.29 & 4.71 & 4.96 \\
\hline & & \multicolumn{5}{|c|}{ Mean effect of year } \\
\hline & 2013 & 7.43 & 6.9 & 6.53 & 7.33 & 7.05 \\
\hline & 2014 & 1.57 & 3.97 & 3.97 & 2.17 & 2.92 \\
\hline & 2015 & 5.23 & 4.47 & 5.37 & 4.63 & 4.92 \\
\hline
\end{tabular}

$\mathrm{LSD}_{0.05}$

$\mathrm{A}=\mathrm{NS}, \mathrm{B}=2.12, \mathrm{C}=2.12$

$\mathrm{A} / \mathrm{B}=\mathrm{NS}, \mathrm{B} / \mathrm{A}=\mathrm{NS}, \mathrm{A} / \mathrm{C}=\mathrm{NS}$

$\mathrm{C} / \mathrm{A}=\mathrm{NS}, \mathrm{B} / \mathrm{C}=2.69, \mathrm{C} / \mathrm{B}=2.69$

In spring seasons, the fastest growth was observed on lawns with perennial ryegrass $\left(3.95^{\circ}\right)$ and the slowest for red fescue $\left(6.33^{\circ}\right)$, with the differences being statistically significant. Considering the effect of soil conditioners on different grass species, it was noted that perennial ryegrass treated with Substral and smooth-stalked meadow-grass treated with UGmax grew the fastest $\left(3.6^{\circ}\right.$ and $3.7^{\circ}$, respectively). In turn, the slowest growth was on lawns with red fescue, with its responses to different soil conditioners ranging from $6.2^{\circ}$ to $6.43^{\circ}$.

In assessing grass growth in spring throughout the research, it was found that the most intensive growth was in 2014 (the average of $2.92^{\circ}$ ) and the least in $2013\left(7.05^{\circ}\right)$, with those differences between the effects of spring seasons being statistically significant. In springtime the type of applied soil conditioner had a greater impact on grass growth level than weather conditions. As regards the values of precipitation and air temperature (Table 2), the worst weather conditions occurred in the spring of 2015, when the intensity of grass growth was moderate (the average rate of $4.92^{\circ}$ ). In the spring of 2013 weather conditions were very conducive to grass growth (the average air temperature of $7.5^{\circ} \mathrm{C}$ in April, $15.3^{\circ} \mathrm{C}$ in May, and $17.7^{\circ} \mathrm{C}$ in June, and the precipitation of 57.6, 145.8, $111.9 \mathrm{~mm}$, respectively), while the intensity of grass growth was the weakest $\left(7.05^{\circ}\right)$, comparing with the other spring seasons of the research. According to 
Martiniello and D'Andrea (2006) in warm and humid habitats, growth of green mass is faster and lusher. However, the excessive increase in air temperature, together with strong evaporation, can undermine the balance between energy spent on respiration and on accumulation of photosynthetic products necessary for growth.

\section{Summer grass regrowth}

In summer seasons, intensity of grass growth was also varied (Table 4), and, like in spring, perennial ryegrass grew the fastest (4.28) and red fescue the most slowly (6.54). Studying the effects of soil conditioners on different species it was found that, like in spring, the most intensive growth was on plots with perennial ryegrass treated with Substral $\left(2.67^{\circ}\right)$ and on plots with smooth-stalked meadow-grass treated with UGmax $\left(2.6^{\circ}\right)$. In turn, smooth-stalked meadow-grass and red fescue had the slowest growth when treated with Humus Active Papka $\left(7.6^{\circ}\right.$ and $\left.7.43^{\circ}\right)$.

Table 4. Grass growth rates on a 9-point scale in summer seasons between 2013 and 2015

\begin{tabular}{|c|c|c|c|c|c|c|}
\hline \multirow{2}{*}{$\begin{array}{l}\text { Year } \\
\text { (C) }\end{array}$} & \multirow{2}{*}{$\begin{array}{l}\text { Species } \\
\text { (B) }\end{array}$} & \multicolumn{4}{|c|}{ Fertiliser (A) } & \multirow{2}{*}{$\bar{x}$} \\
\hline & & (S) & (EU) & (HAP) & (UG) & \\
\hline \multirow{3}{*}{2013} & $\begin{array}{l}\text { Smooth-stalked meadow- } \\
\text { grass }\end{array}$ & 2.1 & 8.9 & 8.6 & 2.9 & 5.63 \\
\hline & Perennial ryegrass & 2.9 & 7.8 & 8.4 & 4.1 & 5.8 \\
\hline & Red fescue & 4.8 & 7.7 & 8.2 & 5.3 & 6.5 \\
\hline \multirow{3}{*}{2014} & $\begin{array}{l}\text { Smooth-stalked meadow- } \\
\text { grass }\end{array}$ & 3.2 & 9.0 & 8.9 & 2.9 & 6.0 \\
\hline & Perennial ryegrass & 2.9 & 6.9 & 7.2 & 3.2 & 5.05 \\
\hline & Red fescue & 5.2 & 4.9 & 5.1 & 4.7 & 4.98 \\
\hline \multirow{3}{*}{2015} & $\begin{array}{l}\text { Smooth-stalked meadow- } \\
\text { grass }\end{array}$ & 4.9 & 2.4 & 5.3 & 2.0 & 3.65 \\
\hline & Perennial ryegrass & 2.2 & 1.9 & 2.0 & 1.8 & 1.98 \\
\hline & Red fescue & 8.9 & 6.9 & 9.0 & 7.8 & 8.15 \\
\hline & & \multicolumn{5}{|c|}{ Mean effect of species } \\
\hline \multirow{3}{*}{\multicolumn{2}{|c|}{$\begin{array}{c}\text { Smooth-stalked meadow-grass } \\
\text { Perennial ryegrass } \\
\text { Red fescue }\end{array}$}} & 3.4 & 6.77 & 7.6 & 2.6 & 5.09 \\
\hline & & 2.67 & 5.53 & 5.87 & 3.03 & 4.28 \\
\hline & & 6.3 & 6.5 & 7.43 & 5.93 & 6.54 \\
\hline & & \multicolumn{5}{|c|}{ Mean effect of fertiliser } \\
\hline & & 4.12 & 6.27 & 6.97 & 3.86 & 5.31 \\
\hline & & \multicolumn{5}{|c|}{ Mean effect of year } \\
\hline & 2013 & 3.27 & 8.13 & 8.4 & 4.1 & 5.98 \\
\hline & 2014 & 3.77 & 6.93 & 7.07 & 3.6 & 5.34 \\
\hline & 2015 & 5.33 & 3.73 & 5.43 & 3.87 & 4.59 \\
\hline
\end{tabular}

$\mathrm{LSD}_{0.05}$

$\mathrm{A}=2.55, \mathrm{~B}=\mathrm{NS}, \mathrm{C}=\mathrm{NS}$

$\mathrm{A} / \mathrm{B}=2.05, \mathrm{~B} / \mathrm{A}=1.84, \mathrm{~A} / \mathrm{C}=2.05$

$\mathrm{C} / \mathrm{A}=1.84, \mathrm{~B} / \mathrm{C}=1.59, \mathrm{C} / \mathrm{B}=1.59$

The slowest growth in summer, taken as an average for all grass species, was caused by Humus Active Papka $\left(6.97^{\circ}\right)$ and the fastest by UGmax $\left(3.86^{\circ}\right)$. These results confirmed the justification of the use of those soil conditioners on lawns. According to Hamza and Suggars (2001) bio products are based on natural substances like plant extracts, phyto hormones, or humic substances. Therefore, they have positive impact on plant metabolism, stimulating life processes to overcome adverse environmental conditions.

Throughout the experiment grass growth varied in summer seasons. The worst weather conditions for the development of grass occurred in 2015 (the air temperature 
of 18.7 in July and 21.0 in August and precipitation of 62.6 and $11.9 \mathrm{~mm}$, respectively), which was not reflected in slow growth. In 2015 the average value of this parameter for all species was 4.59, which was the fastest growth of all three summer seasons, suggesting that like in the spring, it was more dependent on the type of applied soil conditioners than on weather conditions. Of all summer seasons throughout the entire research grass had the slowest growth (best) in 2013, when treated with Humus Active Papka $\left(8.4^{\circ}\right)$ or Eko-Użyźniacz $\left(8.13^{\circ}\right)$. According to Calvo et al. (2014) this type of bio products facilitates assimilation of nutrients, which in turn affects metabolism of plants and at the same time quality of a lawn, like grass density or growth rate. In the present experiment grass treated with Substral had the worst, from the point of view of the user, growth rate in $2013\left(3.27^{\circ}\right)$. Differences in the intensity of growth between applied soil conditioners in various years of research were statistically significant.

In other studies (Jankowski et al., 2011; Salehi and Khosh-Khui, 2004) it was found that the regrowth of lawn grass in monoculture was mainly dependent on the species of grass selected to be planted, as well as on the year of the studies, which was associated with weather conditions.

\section{Autumn grass regrowth}

In the autumn the intensity of grass growth was also varied (Table 5). Among the species of grass, perennial ryegrass had the most intensive growth $\left(3.62^{\circ}\right)$, similar to previous seasons (spring, summer), while red fescue had the slowest growth $\left(5.85^{\circ}\right)$. Differences in the intensity of growth between these species were statistically significant. Looking for best species and varieties of grass to be used on extensive lawns, Prończuk and Prończuk (2006) found that red fescue tolerated lack of nutrients in the soil better than other species. It is obvious that mineral fertilizers, mainly nitrogen, stimulate the growth and growth rate of grass.

\section{Grass regrowth in regard to soil conditioners, species and study year}

Throughout the three-year period red fescue treated with UGmax had the slowest (the best) growth $\left(6.1^{\circ}\right)$ and perennial ryegrass with UGmax the most intensive (the worst) $\left(2.97^{\circ}\right)$. Of the applied soil conditioners Humus Active Papka had the biggest effect on slowing grass growth $\left(5.08^{\circ}\right)$. Throughout the research there were statistically significant differences in the intensity of growth in autumn, in which season lawn grass grew the most quickly in $2014\left(3.83^{\circ}\right)$, while in 2013 the growth was the slowest $\left(5.53^{\circ}\right)$. In various years of research the differences in the intensity of grass growth with different soil conditioners applied were statistically significant. In other studies Jankowski et al. $(2012 \mathrm{~b}, \mathrm{e})$ found that due to different weather conditions in various years of research there were also important significant differences in grass growth. Trinexapak ethyl used in the experiment conducted by the above authors showed favourable interaction between grass and mineral soil conditioners in terms of growth rate.

In assessing the intensity of grass growth (Table 6) as an average of all experimental years it was found that red fescue had the slowest growth (the average of $6.24^{\circ}$ ), and perennial ryegrass the fastest (the average of $3.95^{\circ}$ ). These differences were statistically significant. Of all species, red fescue treated with Humus Active Papka had the slowest growth of $6.44^{\circ}$, as the three-year average. Comparing the effects of soil conditioners it was found that Humus Papka had the best ability to slow the intensity of grass growth, with the growth rate of $5.78^{\circ}$, determined as an average for all species. 
Table 5. Grass growth rates on a 9-point scale in autumn seasons between 2013 and 2015

\begin{tabular}{|c|c|c|c|c|c|c|}
\hline \multirow{2}{*}{$\begin{array}{l}\text { Year } \\
\text { (C) }\end{array}$} & \multirow{2}{*}{$\begin{array}{l}\text { Species } \\
\text { (B) }\end{array}$} & \multicolumn{4}{|c|}{ Fertiliser (A) } & \multirow{2}{*}{$\bar{x}$} \\
\hline & & (S) & $(\mathbf{E U})$ & (HAP) & (UG) & \\
\hline \multirow{3}{*}{2013} & $\begin{array}{l}\text { Smooth-stalked meadow- } \\
\text { grass }\end{array}$ & 6.9 & 4.8 & 5.1 & 7.4 & 6.05 \\
\hline & Perennial ryegrass & 4.8 & 5.1 & 7.2 & 4.9 & 5.5 \\
\hline & Red fescue & 4.9 & 4.8 & 5.2 & 5.3 & 5.05 \\
\hline \multirow{3}{*}{2014} & $\begin{array}{l}\text { Smooth-stalked meadow- } \\
\text { grass }\end{array}$ & 5.0 & 4.8 & 4.9 & 3.8 & 4.63 \\
\hline & Perennial ryegrass & 3.1 & 4.1 & 4.0 & 1.9 & 3.28 \\
\hline & Red fescue & 4.2 & 3.0 & 2.9 & 4.3 & 3.6 \\
\hline \multirow{3}{*}{2015} & $\begin{array}{l}\text { Smooth-stalked meadow- } \\
\text { grass }\end{array}$ & 4.6 & 5.2 & 5.4 & 5.0 & 5.05 \\
\hline & Perennial ryegrass & 1.9 & 2.3 & 2.0 & 2.1 & 2.08 \\
\hline & Red fescue & 9.0 & 8.9 & 9.0 & 8.7 & 8.9 \\
\hline & & \multicolumn{5}{|c|}{ Mean effect of species } \\
\hline \multirow{6}{*}{\multicolumn{2}{|c|}{$\begin{array}{c}\text { Smooth-stalked meadow-grass } \\
\text { Perennial ryegrass } \\
\text { Red fescue } \\
\end{array}$}} & 5.5 & 4.93 & 5.13 & 5.4 & 5.24 \\
\hline & & 3.27 & 3.83 & 4.4 & 2.97 & 3.62 \\
\hline & & 6.03 & 5.57 & 5.7 & 6.1 & 5.85 \\
\hline & & \multicolumn{5}{|c|}{ Mean effect of fertiliser } \\
\hline & & 4.93 & 4.78 & 5.08 & 4.82 & 4.9 \\
\hline & & \multicolumn{5}{|c|}{ Mean effect of year } \\
\hline & 2013 & 5.53 & 4.9 & 5.83 & 5.87 & 5.53 \\
\hline & 2014 & 4.1 & 3.97 & 3.93 & 3.33 & 3.83 \\
\hline & 2015 & 5.17 & 5.47 & 5.47 & 5.27 & 5.35 \\
\hline
\end{tabular}

$\mathrm{LSD}_{0.05}$

$\mathrm{A}=\mathrm{NS}, \mathrm{B}=1.73, \mathrm{C}=1.73$

$\mathrm{A} / \mathrm{B}=\mathrm{NS}, \mathrm{B} / \mathrm{A}=\mathrm{NS}, \mathrm{A} / \mathrm{C}=\mathrm{NS}$

$\mathrm{C} / \mathrm{A}=\mathrm{NS}, \mathrm{B} / \mathrm{C}=1.54, \mathrm{C} / \mathrm{B}=1.54$

Table 6. The effect of soil conditioners and species on annual grass growth rates on a 9point scale between 2013 and 2015

\begin{tabular}{|c|c|c|c|c|c|}
\hline \multirow{2}{*}{$\begin{array}{c}\text { Species } \\
\text { (B) }\end{array}$} & \multicolumn{4}{|c|}{ Fertiliser (A) } & \multirow{2}{*}{$\bar{x}$} \\
\hline & (S) & $(\mathbf{E U})$ & (HAP) & (UG) & \\
\hline Smooth-stalked meadow-grass & 4.39 & 5.5 & 6.13 & 3.9 & 4.98 \\
\hline Perennial ryegrass & 3.18 & 4.49 & 4.76 & 3.37 & 3.95 \\
\hline \multirow[t]{3}{*}{ Red fescue } & 6.23 & 6.17 & 6.44 & 6.12 & 6.24 \\
\hline & \multicolumn{5}{|c|}{ Mean effect of fertiliser } \\
\hline & 4.6 & 5.39 & 5.78 & 4.46 & 5.06 \\
\hline \multicolumn{6}{|l|}{$\mathrm{LSD}_{0.05}$ dla: $\mathrm{A}=1.40, \mathrm{~B}=1.08$} \\
\hline & \multicolumn{5}{|c|}{ Mean effect of year } \\
\hline 2013 & 5.41 & 6.64 & 6.92 & 5.77 & 6.19 \\
\hline 2014 & 3.16 & 4.96 & 4.99 & 3.03 & 4.04 \\
\hline 2015 & 5.24 & 4.56 & 5.42 & 4.59 & 4.95 \\
\hline \multicolumn{6}{|l|}{$\mathrm{LSD}_{0.05}$ dla: $\mathrm{A}=\mathrm{NS}, \mathrm{C}=1.28$} \\
\hline & \multicolumn{5}{|c|}{ Season (D) } \\
\hline Spring & 4.74 & 5.11 & 4.22 & 4.71 & 4.7 \\
\hline Summer & 4.12 & 6.27 & 6.97 & 3.86 & 5.31 \\
\hline Autumn & 4.93 & 4.78 & 5.08 & 4.82 & 4.9 \\
\hline
\end{tabular}

These results were confirmed by studies of other authors (Pooya et al., 2013; Jankowski et al., 2012a), who found that growth of lawn grass is an unstable feature, depending on the species, habitat conditions, content of macro-and micronutrients in the soil, and on the way the lawn is used. 
Similarly, throughout the years of research there was a varied intensity of grass growth. The slowest growth was achieved in 2013 as a result of treatment with Humus Active Papka $\left(6.92^{\circ}\right)$. Similarly, in the following years of research on the same experimental units the growth was slow. According to many authors (Jankowski et al., 2011; Prończuk and Prończuk, 2008; Knot et al., 2017) lawn grass species, in addition to ensuring good appearance of a lawn, should be characterized by slow growth after mowing.

Determined as an average of all separate seasons (spring, summer, autumn) growth rate was the slowest in summer seasons $\left(5.31^{\circ}\right)$. According to Martiniello and D'Andrea (2006) a decrease in growth and a smaller weight gain of grass during summer months is a natural phenomenon and to a large extent depends on temperature. Air temperature above $30^{\circ} \mathrm{C}$ can completely stop weight gain of grass by stepping up the process of breathing. Among the applied soil conditioners in the summer, lawn treated with Humus Active had the slowest growth rate $\left(6.79^{\circ}\right)$. In the autumn grass in the same experimental unit had the least intensive growth, too.

\section{Grass regrowth variation}

The calculated coefficient of variation of grass growth (Table 7) indicated that during the experiment the smallest variation of this parameter was for red fescue (39.1), with the slowest average growth (6.24), a feature most awaited by the user of the lawn.

Table 7. Standard deviation and coefficient of variation of grass growth rate

\begin{tabular}{c|c|c|c|c|c}
\hline Species & Min. & Max. & Mean & $\begin{array}{c}\text { Standard } \\
\text { deviation }\end{array}$ & $\begin{array}{c}\text { variation } \\
\text { coefficient }\end{array}$ \\
\hline $\begin{array}{c}\text { Smooth-stalked } \\
\text { meadow-grass }\end{array}$ & 1 & 9 & 4.98 & 2.17 & 43.57 \\
Perennial ryegrass & 1.4 & 8.4 & 3.95 & 2.18 & 55.19 \\
Red fescue & 1.8 & 9 & 6.24 & 2.44 & 39.10 \\
\hline
\end{tabular}

variation coefficient: $0-20 \%$ small variation, $20-40 \%$ average variation,

$40-60 \%$ large variation, $>60 \%$ very large variation

\section{Conclusions}

1. Growth rate was varied in relation to both the species of grasses (smooth-stalked meadow grass, perennial ryegrass, red fescue), the applied soil conditioner, and seasons and years of research.

2. In all seasons red fescue had the most desirable intensity of growth (the slowest) and permanent ryegrass the fastest, both determined as an average effect of all soil conditioners.

3. Of the applied soil conditioners, lawns treated with Humus Active Papka, containing in their composition not only a large amount of minerals but also permanent active humus with useful microorganisms, grew the most slowly, taken as an average for all grass species and for all seasons (spring, summer, autumn).

4. Among the species of grass, it was found that in the spring red fescue treated with Eko-Użyźniacz had the slowest growth of grass. In summer both smoothstalked meadow-grass and red fescue treated with Humus Active Papka and in autumn red fescue treated with UGmax grew the most slowly. This proves the 
equivocal effect of soil conditioners on the level of growth rate of various grass species at different times of the year.

5. Of all seasons (spring, summer, autumn) it was found that, as an average for all species, grass grew the most slowly in summer and most intensely in springtime. This could be related to physiological development of grass as well as to the effects of the weather. During summer seasons grass treated with Humus Active Papka had the slowest growth, but it was the fastest as a result of the use of UGmax or Substral.

6. Of all grass species tested in the experiment red fescue had the smallest variation of growth intensity during the research, which, from a practical point of view, is a feature most appreciated by the user, as such grass does not require frequent mowing. In addition, Humus Active Papka deserves further attention as regards its potential for reducing grass growth.

\section{REFERENCES}

[1] Calvo, P., Nelson, L., Kloepper, J. W. (2014): Agricultural uses of plant biostumulants. Plant Soil 383: 3-41.

[2] Chen, Y., Clapp, C. E., Magen, H. (2004): Mechanisms of plant growth stimulation by humic substances: the role of organo-iron complex. - Soil Science and Plant Nutrition 50(7): 1089-1095.

[3] Cook, T. (2005): Low maintenance turf? On line: ttp//ergonstate.edu./dept/hort/turf/ ecolawns.

[4] Czeluściński, W., Jankowski, K., Sosnowski, J., Malinowska, E., Wisniewska-Kadżajan, B. (2017): Effects of trinexapac-ethyl on turfgrass growth and frequency of mowing. Applied Ecology and Environmental Research 15(3): 739-746.

[5] Domański, P. (1998): Methodology of economic value analysis of cultivated plant varieties. Turf grasses: red fescue, tymothy, meadow grass, ryegrass. - COBORU, Słupia Wielka 35.

[6] Domański, P. J., Andrzejewska, J. (2011): Effect of utilization intensity on growth of lawn cultivars of Kentucky bluegrass (Poa pratensis L.). - Acta. Sci. Pol. Agricultura 10(3): 15-26.

[7] Gąbka, D., Wolski, K. (2008): The effect of biopreparations on early stage of growth of selected grass species used for reclamation of municipal waste dumps. Biostimulators in modern agriculture. - Ornamental and special plants, Warszawa, 7-14.

[8] Hamza, B., Suggars, A. (2001): Biostimulants: Myth and Realities. - TurfGrass Trends, Aug, 6-10.

[9] Harkot, W., Czarnecki, Z. (1998): Dynamics of lengthening of the root system of seedlings of Polish varieties of lawn grasses on the soil with damaged and improved top layer. - Ann. UMCS Agric. Sect. E. vol. LIII, 20: 177-184. (In Polish)

[10] Jankowski, K., Ciepiela, A. G., Jodełka, J., Kolczarek, R. (1999a): Comparing analisis of lawn mixtures cultivated in Podlasie region. - Fol. Univ. Agric. Stetin. Agric. 197 (75): 133-140. (In Polish)

[11] Jankowski, K., Kolczarek, R., Ciepiela, A. G. (1999b): Evaluation of some lawn Grass species extensive cultivated. - Fol. Univ. Agric. Stetin. Agric. 197 (75): 147-152. (In Polish)

[12] Jankowski, K., Czeluściński, W., Jankowska, J., Sosnowski, J. (2011): The effect of hydrogel and different fertilisers on the regrowth rate of lawns composed of perennial ryegrass. - Water-Environment-Rural Areas 11, 2(34): 73-82. 
[13] Jankowski, K., Jankowska, J., Sosnowski, J. (2012a): Estimation of turf lawns regrowth with tufted haigrass share. - Folia Pomer. Univ. Technol. Stetin. Agric., Aliment., Pisc., Zootech. 295(22): 21-28. (In Polish)

[14] Jankowski, K., Jankowska, J., Sosnowski, J. (2012b): The regrowth of lawns founded on red fescue base in depended on the applied hydrogel and the kind fertilizers. - Fragm. Agronom. 29(2): 60-67. (In Polish)

[15] Jankowski, K., Czeluściński, W., Jankowska, J., Kolczarek, R., Sosnowski, J. (2012 c): The influence of the growth regulator Trinexapak-ethyl on the regrowth rate of lawn grasses. - Acta Sci. Pol., Hortorum Cultus 11(4): 67-76.

[16] Jankowski, K., Czeluściński, W., Jankowska, J., Sosnowski, J., Wiśniewska-Kadżajan, B. (2012d): The influence of different mushroom's refuse dose on the features quality of turf lawns. - Folia Pomer. Univ. Technol. Stetin. Agric., Aliment., Pisc., Zootech. 295(22): 13-20. (In Polish)

[17] Jankowski, K., Czeluściński, W., Jankowska, J., Sosnowski, J., Wiśniewska-Kadżajan, B. (2012e): Effect of various doses of mushroom's refuse on the regrowth degree of turf lawns. - Folia Pomer. Univ. Technol. Stetin. Agric., Aliment., Pisc., Zootech. 296(23): 35-42. (In Polish)

[18] Jankowski, K., Sosnowski, J., Truba, M., Skrzyczyńska, J., Malinowska, E., WiśniewskaKadżajan, B. (2017): Impact of soil conditioners and weather on lawn compactness. Applied Ecology and Environmental Research 15(4): 1917-1928.

[19] Knot, P., Hrabe, F., Hejduk, S., Skladanka, J., Kvasnovsky, M., Hodulikova, L., Caslavova, I., Horky, P. (2017): The impacts of different management practices on botanical composition, quality, colour and growth of urban lawns. - Urban Forestry \& Urban Greening 26: 178-183.

[20] Martiniello, P., D'Andrea, E. (2006): Cool-season turf grass species adaptability in Mediterranean environments and quality traits of varieties. - Europ. J. Agronomy 25: 234-242.

[21] Pooya, E. S., Tehranifar, A., Shoor, M., Selahvarzi, Y., Ansari, H. (2013): The use of native turf mixtures to approach sustainable lawn in urban landscapes. - Urban Forestry \& Urban Greening 12: 532-536.

[22] Prończuk, S., Prończuk, M. (2006): Search of grass species and cultivars for ecological lawns. - Zesz. Nauk. UP we Wrocławiu, Rolnictwo LXXXVIII, 545:241-248.

[23] Prończuk, M., Prończuk, S. (2008): Search of Kentucky bluegrass [Poa pratensis] cultivars and ecotypes for low maintenance turf. - Biul. IHAR 248: 147-159. (In Polish)

[24] Rutkowska, B., Dębska-Kalinowska, Z. (2000): The usefulness of grass species and varieties on lawns. - Wieś Jutra 4(21): 19-22. (In Polish)

[25] Salehi, H., Khosh-Khui, M. (2004): Turfgrass monoculture cool-cool and cool-warm season seed mixture establishment and growth responses. - HortScience 39(7): 17321735 .

[26] Skowera, B., Puła, J. (2004): Pluviometric extreme conditions in spring season in Poland in the years 1971-2000. - Acta Agrophysica 3(1):171-177. 